\title{
Water and religion
}

\author{
CARDINAL TURKSON
}

ROMAN CATHOLIC CHURCH

From the point of view of the Holy See, as a Church institution and a faith group, water is not just an ecological theme. It is an essential element of life and a profoundly polyvalent spiritual symbol. Though intimately related, the two values require particular attention and studies to precisely reveal the nature of their relationship.

Thus, beginning with a consideration of the wealth of symbolic values and applications of water in religions, but especially in Christianity, we shall proceed to consider, from the point of view of the Holy See, its ecological significance for the life of the human person and his/her world: its great necessity for life, and its presence and availability to the human family and its 'garden home', the earth. The necessity of water for life leads to the Church's description of a 'right to water'. The latter case of the presence and availability of water for all and for the earth have resulted in the Church's describing water as a 'common good' and a 'common patrimony' of the human family and of the earth.

All of this must now be considered in the context of the phenomenon of climate change. Climate change is believed to manifest itself most patently, and its effects most felt, in changes in the water cycle, namely, in the delicate balance between evaporation and precipitation. Indeed, 'water is the primary medium through which climate change influences the earth's ecosystems and, therefore, people's livelihoods and well-being.' It is, therefore, about water, its availability or its lack, and the weather. 'Weather' is the atmospheric condition, based on the sun, of a place at a particular time. When this weather is studied over a long period, it describes a 'pattern' that is called 'climate'. As the climate changes, so the atmospheric conditions also change, causing temperatures to rise or fall. The rise in temperatures causes droughts (water insecurity and unsafe water), storms and floods, melting glaciers, rising sea levels, etc.; falling temperatures cause freezing conditions. 


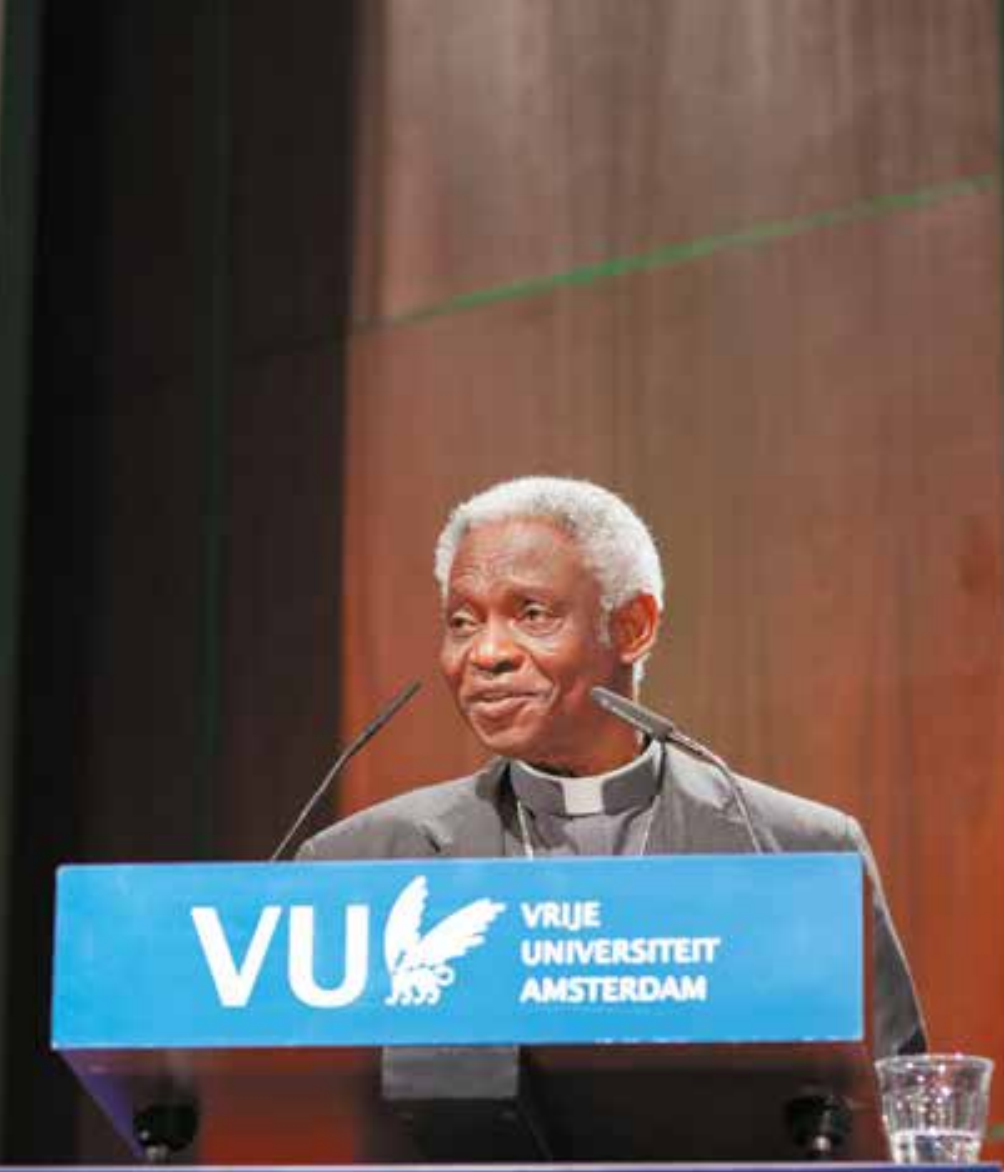

\section{Water as a source of life on earth and religious symbolism}

In many religious traditions, including Christianity, water is a primordial element, and it is believed to be the fons vitae, the very source of life. The Scriptures of biblical religions (Judaism and Christianity) begin with the narrative of the creation of the world, where the hovering of the Spirit of Elohim (God) over the waters (Gen I:I-2) sets the scene for the creation of all that exists (cf. Gen I:6-7, 9-10, 20-2I).

Today's science confirms this to be true, namely, that at the origin of all things is water. Accordingly, what makes the earth unique in the known cosmos is the presence of water on it: and water as the source of all life. But water only exists on earth because the planet is positioned within a specific narrow band around its mother star, known as the Goldilocks Zone. This position of the globe at an optimal distance from the Sun makes it possible to have water on its surface and, thus, for the garden home of humanity and its oceans to be the womb of life on 
the planet. In this regard, not only do scientists affirm the origins of life in water, they also claim that life is possible only if the availability and presence of water is continuous.

Water covers over two thirds of the surface of our planet; and an almost equivalent proportion of the body mass of every adult human is composed of water. So, naturally, water is the most potent symbol of life.

\section{Water as source of human and divine life}

For Christians, water is an element that communicates not just ordinary life, but God's presence and divine grace. On account of its natural cleansing powers, water is used in several religious rites of purification and atonement. It is also an essential element of several rituals that promise and ensure reconciliation and wholesomeness of the human body, of human life and of human relationships.

It is used in several Christian and traditional rituals of initiation (rites de passage) to mark a passage to maturity and adulthood, or, in the case of the Christian rite of baptism, that symbolises the passage from death to life. This Christian initiation rite is prefigured in the biblical story of Ancient Israel's crossing through the waters of the Red Sea to mark its deliverance from Egyptian bondage for a life of freedom, as God's people (Ex I3-I4). In its current celebration as baptism or a Christian rite of initiation, the waters of the Red Sea are replaced wit baptismal waters. When someone is immersed in this water, or when it is poured onto someone, their old way of life (of sin or living for oneself) dies in order to embrace a new life of living in God's love and for mutual service (well-being) (cf. IPt 3:20). Because of the fundamental significance of Baptism as a rite of purification and a rite of passage to becoming a member of a religious group, the Catholic Church, for example, precedes gatherings to celebrate the life of communion of its members in the Eucharist with a reminder of their baptism: their washing by water and the Holy spirit, in a rite of sprinkling with water called the 'asperges'. Referencing biblical passages such as Ezek 36:25ff., Titus 3:5, and Hebrews 10:22, the rite of 'asperges' recalls baptism, when the faithful were purified for a new life with their Lord in the Eucharist.

Finally, on account of its natural cleansing power, water is blessed, in turn, used to bless and purify objects and persons that are dedicated to deities and intended for divine purposes. As a corollary, what is set aside for divine purpose also enjoys a special divine protection.

In this sense, water is used in many popular rites at shrines and places of pilgrimage, such as in Lourdes, in France, as a source of healing. 


\section{Water as a source of illiness, violence, and death}

If water is the source of life for all of our planet's creatures and human beings, then the pollution and contamination of water due to agro-chemicals, cultural habits related with poor sanitation, extractive industries, and other industrial uses must be considered sinful (cf. Laudato Si', 8). Indeed, the lack of access to fresh and clean water is one of the main causes of death and disease. According to statistics, one in every two sick people in the world suffers from symptoms linked to a lack of good drinking water or from the use of contaminated water. Around $8 \circ$ per cent of diseases in the developing world and one in three deaths there are linked to the use of polluted water. More children are killed by dirty water than by war, malaria, HIV/AIDS, and traffic accidents combined. Every eight seconds, a child dies from drinking dirty water.

Water scarcity is increasingly becoming a source of serious conflict. A tendency to consider water as a marketable commodity rather than a common good and a common endowment of our common home, the earth, means that our water management strategies are adversely affecting the poor. Access to water is a source of global inequality. (cf. Laudato Si, 28-29, 48).

Syria is a case in point: the country suffered its worst drought in history and, consequently, a record crop failure in the period 2006-2010. As a result, I.5 million people in Syria have emigrated from rural farming communities to urban areas. While this was not the cause of the civil war, it certainly fanned the flames.

Another case in point is the Sahel region of West Africa. Here, droughts provoke the incessant conflicts between pastoralists and farming communities. The pastoralists are predominantly Fulani Muslims and the agricultural communities predominantly animist and Christian. Consequently, the conflicts tend to assume a religious character, fomenting religious tensions in communities that are all too readily exploited by arms traffickers.

Similarly motivated are the systematic threats to and the killings of environmental activists in Latin America. At a recent synod on the Amazon, bishops and leaders of indigenous communities frequently spoke of the systematic killing of environmental activists: the avowed carers of our common home! The emerging and rising tensions between environmental caretakers and 'developers' of natural resources in the region point to conflicts that are destined to become more acrimonious and frequent as the fall-out of climate change becomes increasingly severe. 


\section{Spirituality and caring for water}

In order to address the issue of water being corrupted, from a source of life into a source of conflict and death, Pope Francis invites us all to join forces and work together for the radical change of an ecological conversion. This change is urgently needed in policy formulations, laws, and regulations, but most importantly it is vital if we are to cultivate sound ecological virtues (cf. Laudato $S_{i}, 2$ II ). Such virtues will change habits and develop an attitude of caring for the earth's resources, especially water! We must be prudent in our use and disposal of water, and ensure that everybody has access to this vital natural resource. In fact, the right to water is crucial to the pursuit of other rights, because without water there is no life. According to the Catholic social tradition, the obligations regarding the right to water extend across space (the entire world and human community) and time (for future generations).

In short, we need specific persons and communities to educate others in 'ecological citizenship': an education system that creates a 'bold cultural revolution' (Laudato Si, II 4); one that helps reduce the socio-ecological debt created by the disparity of access to clean water (cf. Laudato $\mathrm{Si}^{\prime},{ }_{30}$ ), which is also symptomatic of the disparities in access to food, health, and a good life (cf. Laudato Si, 3I).

Religious communities have a special responsibility in this regard. In the case of the Catholic Church, our use of water in the sacraments (God's privileged presence in our life) can help us re-value water as a source of life. Water unites us, it is the source of life - for the earth, for creatures, and for humans. But water is also the symbol of eternal life. To leave millions of sisters and brothers and some ecosystems without access to water is not God's intention; it is a sin. Conversely, to care for water and to ensure its availability, as a universal good that is shared amongst us all, is to echo God's invitation: 'Come to the water all you who are thirsty; though you have no money, come!' (Is 55:I).

Such a frame of mind and heart fosters a profound interest in caring for water; and it certainly constitutes a spiritual inspiration for the moral stance that the Church takes in its teachings on the matter and in its interventions at international meetings. 


\section{The Holy See and World Summits \& Discussions on Water}

\section{A) The right to Water, as a Common good:}

Pope Pius XI taught the Church and the world that, 'created things may serve the needs of mankind in fixed and stable order.' Accordingly, in 1961, when Pope John XXIII was dealing with the problem of the drift of rural and agricultural population into cities, he proposed a solution that included the provision to ensure 'drinking water' in rural areas. A year later, Pope John XXIII convoked the Vatican Council II (1962). He did not live to conclude the Council, but its document on the role of the Church in the Modern World, 'Gaudium et Spes', deals explicitly with the theme of life (indeed, it is mentioned 200 times) and the place and dignity of the human person in the world: "[...] all things on earth should be related to man as their center and crown."

In 1965, St. Pope John XXIII's successor, Pope Paul VI, concluded the Vatican Council II. However, in his previous travels to Latin America (1960) and to Africa (1962), as Archbishop of Milan, and later, to India, as Pope, St. Pope Paul VI identified the issue of 'underdevelopment' as the great 'social question' of his times; an issue that his Encyclical Letter, Populorum Progressio (1967) sought to address. In a brief section of this work, entitled 'Issues and principles', Pope Paul VI stated: 'if the earth truly was created to provide man with the necessities of life and the tools for his own progress, it follows that every man has the right to glean what he needs from the earth.' Here, water is not explicitly mentioned, but the Pope enunciated a principle that enshrines man's right to the goods of creation, including water. Accordingly, Pope Paul VI not only taught us that: '[...] under the leadership of justice and in the company of charity, created goods should flow fairly to all.' He also called for institutions to teach about the relationship between man and creation / nature for man's true development; for, as he observed later (I97I), man is also capable of abusing the created goods that fall to him by right: 'Man is suddenly becoming aware that by an ill-considered exploitation of nature he risks destroying it and becoming in his turn the victim of this degradation.' As we have seen, this certainly includes man's use of water. Paul VI also called for the 'the establishment of a world authority capable of taking effective action on the juridical and political planes' to ensure that the goods of creation ensure man's true development.

As if the United Nations Organization was listening, in 1972 the Stockholm conference launched the UN Program on the Environment (UNEP). Just prior to the launch, Pope Paul convoked the Synod on Justice in the World, 
in November 1972, where this crucial observation was made: '[...] people are beginning to grasp a new and more radical dimension of unity; for they perceive that their resources, as well as the precious treasures of air and water - without which there cannot be life - and the small delicate biosphere of the whole complex of all life on earth, are not infinite, but on the contrary must be saved and preserved as a unique patrimony belonging to all human beings.'

After the very brief pontificate of Pope John Paul I, Pope John Paul II succeeded Pope Paul VI, taking and developing further his teaching on the place of humans in the created world. The thrust of Pope John Paul II's teaching was to extend a moral structure to the ecological question, namely, the relationship between the person and his/her environment (the created world); and these are his considerations: Since 'one cannot use with impunity the different categories of beings, whether living or inanimate - animals, plants, the natural elements [...], one must take into account the nature of each being and of its mutual connection in an ordered system, which is precisely the cosmos.' Secondly, natural resources are limited, and not all are renewable. If we treat them as inexhaustible and use them with absolute dominion, then we seriously endanger their availability in our own time and, above all, for future generations.

Accordingly, humans should not fall into the anthropocentric error of exercising absolute dominion over created goods, because of their capacity to transform, and, in a certain sense, re-create the world through talent and work. Rather, the things that God has created are for our use, to be employed in a responsible way, for man is not the master but the steward of creation. Similarly, when any created goods fall to a person, as a result of the right to private ownership, their use must always be subordinated freely to their original common destination as created goods.

Thus, between the Pope who opened the Vatican Council II and the Pope who closed it, much prominence was given to teaching about access to created goods (including water), as universal goods that rightfully belong to members of the human family. Pope John Paul II deepened this teaching in the context of the relationship between man and his created world: between a human ecology and a natural ecology. In so doing, Pope John Paul II gave a moral structure to man's right to access and use created goods. From this, the teaching of humanity's right to access created goods will become an official and a universal Church teaching in the Compendium of the Social Doctrine of the Church.

Under the pontificate of his successor, Pope Benedict XVI, the study of the relationshipbetween the twoecologies of man and of nature (createdworld) deepened. 
For Pope Benedict XVI, not only does the ecological question (relationship between man and his environment) have a moral structure, it is essentially dependent on and determined by the moral tenor of society. Furthermore, man not only has a right to access the endowments of nature (created goods), he/she also has duties towards them and the environment. Thus, man and is inextricably linked to the world. They are united by a reciprocal relationship, leading Pope Benedict XVI to describe man and his environment as a Book of Nature that is one and indivisible. The human and the natural are bound by a 'covenant relationship', which should mirror the creative love of God; for, the duties of human beings towards the environment and created goods flow from their duties towards each other. The relationship between humans and their environment is deeply ethical and moral is, in the sense of both rights and duties. Thus, humans not only have a right to access and use created goods, like water, but 'matter is not just raw material to be shaped at will; rather, the earth has a dignity of its own and we must follow its directives [...] We must listen to the language of nature and we must answer accordingly.' We know that the human family has not been particularly good at respecting the dignity of nature; and the description of climate change as 'anthropogenic' (originating in human activity) may also entail moral misconduct on the part of humanity.

In Pope Francis, the blend of the rich heritage of the teachings of his predecessors on the environment (created goods) and his pastoral experience in the Regional South American Church of the Aparecida Document fashioned a witness and a strong advocate for the covenant that must exist between the environment (nature) and its dwellers. He has expressed this as the need to care for creation, as integral human development, as concern for the poor and the aged, and as a call to listen to the cry of the earth and of the poor, in his homilies, addresses, and messages to various audiences at and events, as well as in his Apostolic Exhortation. This culminated in the writing of an encyclical on natural and human ecology, Laudato Si'.

In Laudato Si', Pope Francis says: 'When we speak of the "environment", what we really mean is a relationship existing between nature and the society which lives in it. Nature cannot be regarded as something separate from ourselves or as a mere setting in which we live. We are part of nature, included in it and thus in constant interaction with it.'

- Thus, we may synthesise his various pronouncements and treatment of the ecological question (natural \& human ecology or integral ecology) under four headings:

- The call to protect (environment and life) is integral and all-embracing. 
- The care for creation and the respect for the grammar of nature are virtues in their own right.

- The need for education in ecological citizenship to underpin a moral conversion: an ecological conversion to care for what we cherish and revere.

- The recognition that binding regulations, policies and targets are necessary tools for addressing poverty and climate change, but they are unlikely to prove effective without moral conversion and a change of heart. Our efforts at combating, mitigating, or preventing climate change, global warming, poverty, and inhuman conditions require an integral approach to ecology. It cannot be limited to legislation, policies, or merely scientific, economic, or technical solutions. To succeed, whatever is done must be undergirded by an 'ecological conversion': a real conversion of mind, heart, and lifestyle, and in a new global solidarity.

These words of Pope Francis bring to mind Pope John Paul II's call for a 'moral structure' to the ecological question, and Pope Benedict XVI's advertence to the 'moral tenor of society' that is required to deal with the ecological question.

\section{B) The Holy See and international organisations on water (oceans):}

Equipped with this tradition of Church teaching about access to created goods as a right and a common good, even in the different phases of its development, the Church has and continues to engage in international meetings and discussions about such created goods as water, the sea, rivers, groundwater, and glaciers as well as sustainable development more generally (e.g. SDG 6).

Already in 1977, during the third UN Conference on the Law of the Sea (1973-1982), the Holy See Dicastery: Pontifical Commission: Iustitia et Pax, contributed a Working Paper on the universal purpose of created things.

Subsequently, and skipping for now a consideration of the UN MDGs and the SDGs, we may consider the participation of the Holy See in the World Water Forums:

\section{World Water Forums}

Between 2003 and 2012, the Holy See, through its Dicastery for Social issues, the Pontifical Council of Justice and Peace, participated in four World Water Forums, accompanying discussions with a call for the moral consideration of issues. Thus, at Kyoto (2003), the Holy See contributed to the discussion with a position paper, entitled 'Water, an essential element for life'. In this 
paper, the Holy See drew attention to how water fulfils a basic need for the three pillars of sustainable development, namely: the economy, society, and the environment. It described three water-related goods: 'economic good', 'social good', and 'environmental good'. Recognising the lack of these three goods for some people, and the lack of access to potable water in certain areas of the world, the paper raised the issue of access to water as a common good, a necessity of life, an expression or a requirement of a person's dignity and, therefore, a 'right'. Moreover, given its great value and importance the management of water against abuses is an absolute necessity.

At the Forum in Mexico City (2006), the Holy See built on its reflections at Kyoto, now signalling water as a fundamental good of God's creation, destined to serve the good or the well-being of every person. In this sense, the position paper presented at Mexico City identified water as a key factor for peace and security, and stated that created goods are the 'responsibility of all.' In this regard, the paper called for the promotion of a 'culture of water' that values and respects it, and desists from treating it as mere merchandise or a marketable commodity. Hence water must be managed with a keen sense of justice and responsibility.

The sth Water forum in Istanbul (2009) was held against the background of several water challenges in the world. Accordingly, the Holy See position paper bore a sense of urgency. It added to a subtitle to its Kyoto paper: 'Water, an essential Element for Life: And now a matter of greater urgency.' This urgency originated in a persistent lack of access to potable water and hygienic services or sanitation, which makes the right to access to water elusive. Accordingly, the Holy See position paper insisted on a clearer legal formulation of people's right to water.

The World Water Council convoked the 6th World Water Forum in Marseille (2012) under the banner: 'Time for Solutions'. In view of, particularly, two issues: trans-boundary water management and green growth (food security), the Holy See's intervention focused on the role of water for peace and conflict. Motivated by the OECD's call for worldwide water reform, the Holy See delegation highlighted the need to clearly define and uphold the water rights of people and the centrality of the human person, his/her access to created goods, and the primacy of his/her dignity in the management and legislation of created goods, like water. The World Water Council and the Holy See's dialogue continues.

\section{The oceans and the seas}

In June 2017, the UN held a High-Level Conference on the 'Oceans and SDG I4', to which I was privileged to lead a delegation of the Holy See. The 
thrust of the conference was to 'conserve and sustainably use the oceans and marine resources for a sustainable development'. It featured several partnership dialogues, two of which addressed the issues of 'minimizing and addressing ocean acidification, and increasing economic benefits (of the Blue economy) to Small Island developing States and least developed countries, providing access for small scale artisanal fishers to marine resources and markets.'

For the Holy See, taking care of our environment, a gift entrusted to our responsible stewardship, is a moral imperative. Among the many considerations that flow from this fundamental principle are intergenerational solidarity and a focus not merely on rights, but also on responsibilities. Pope Francis has repeatedly affirmed that intergenerational solidarity is not optional, but a basic question of justice, since the world we have received also belongs to those who will follow us. This is reason enough to consider the impact of anthropogenic climate change on the oceans. The oceans and seas should immediately be considered a benefit. They must be viewed as a gift for future generations, too. Moreover, we must spare them from paying the extremely high price of the deterioration of our oceans, seas, and marine resources.

In July 2017, the ambassadors of Monaco, France, and the Netherlands accredited to the Holy See organised a conference with the Dicastery for Promoting Integral Human Development of the Holy See at the Pontifical University of the Holy Cross (Rome), on 'Care for Oceans: The Oceans, Caring for a Common Heritage'. The United Nations was represented at that conference by Mr. Peter Thompson, President of the UN General Assembly; the focus of the event was the impact of climate change on the oceans and seas. The Dicastery's contribution was a reminder that the oceans and their underwater treasures and wonders constitute a 'heritage' to humanity. 'Heritage' makes us recognise that we have inherited these created goods and have a duty to pass them on. It calls for a keen sense of responsibility and of intergenerational solidarity as caretakers.

Many other states, such as Indonesia, the Netherlands, Chile, the United States and Fiji, have held international conferences on the ocean. The decision for Fiji to jointly host the $\mathrm{COP}_{23}$ with Germany, in Bonn (2017), was a signal that we must address the 'cry for help' from Pacific Island States slowly sinking under rising sea levels as a result of climate change. At both $\mathrm{COP}_{23}$ and COP 24, held in Katowice, Poland, the Holy See appealed for a show of 'solidarity' for peoples dealing with the effects of climate change.

In October 2017, the European Union held a conference in Malta for 'a safe, secure, clean and a healthy ocean.' In the background were the challenges of 
African migrants, compelled by climate change conditions to risk crossing the Mediterranean Sea. And a UN working group at the last meeting of the International Maritime Organization in London (26-27 November 2019) eagerly committed to preparing "a new legally binding instrument to expand the Law of the Sea to regulate the conservation and sustainable use of marine biodiversity in areas beyond national jurisdiction in these times of climate change.' The Holy See was there to offer the help of its special apostolate for seafarers and fishers, called 'The Apostleship of the Sea'.

\section{The Stockholm SI WI World Water Week}

Since 2016, the SIWI World Water Week has offered the Holy See (the Dicastery for Promoting Integral Human Development) an annual occasion to engage the world of science, economics, politics, as well as professionals on various waterrelated issues, such as water governance or management, but also water-related challenges, such as the water-climate-economics and poverty-health-sanitation chains.

Thus, the 2016 World Water Week was inspired, initially, by the Encyclical Letter of Pope Francis, Laudato Si' par.I 4: 'I urgently appeal, then for a new dialogue about how we are shaping the future or our planet. We need a conversation which includes everyone, since the environmental challenge we are undergoing, and its human roots, concern and affect us all.' On this basis, the SIWI meeting on 'Faith, Water and Sustainable Development' welcomed input from religious leaders on how their different faiths promote water management for sustainable development in an era of climate change. The Holy See delegation contributed the concept of 'integral development' as a programme of inclusive development that involves the growth of the human family and the well-being of its environment. Well-pursued 'integral development' necessarily requires the adoption of measures of mitigation and adaptation to reduce the impact of climate change. Most importantly, the contribution of water to integral and sustainable development, in situations when the variations of the water cycle are causing climate change, requires the development, by all, of a serious water culture, a keen education in ecological citizenship for an ecological conversion that enshrines a deep respect for created goods, the miracle of creation, and a profound sense of stewardship or 'caretaking' of God's gift to humanity. 